\title{
Demokrasi Negara Melalui Gerakan Indonesia Baru
}

\author{
Musdalifah Qadariah NIM 2161B0026 \\ Institut Ilmu Kesehatan Strada Indonesia \\ musdalifahqadariah2002@gmail.com
}

\begin{abstract}
Abstrak
Indonesia adalah negara kesatuan yang pemerintahannya berlandaskan pada sistem politik demokrasi. Demokrasi meletakkan rakyat pada posisi penting, hal ini karena masih memegang teguh rakyat selaku pemegang kedaulatan. Demokrasi adalah bentuk pemerintahan di mana semua warga negaranya memiliki hak yang sama pengambilan keputusan yang dapat mengubah hidup mereka.Kebebasan berserikat, kemerdekaan berpendapat, kebebasan pers, dan sebagainya yang merupakan ciri-ciri demokrasi. Gerakan sosial baru muncul seiring dengan perubahan bentuk masyarakat. Perkembangan masyarakat kekinian tentu juga menjadi pertimbangan perihal bagaimana mengamati bentuk gerakan sosial yang muncul, strategi yang digunakan, serta visi dan perubahan yang ingin dicapai. Dengan demikian tujuan dari gerakan sosial baru adalah untuk menata kembali relasi negara, masyarakat dan perekonomian dan untuk menciptakan ruang publik yang di dalamnya terdapat wacana demokratis otonomi dan kebebasan individual.
\end{abstract}

\section{Latar Belakang}

Indonesia merupakan negara kesatuan yang sistem politik pemerintahannya berlandaskan pada demokrasi. Menilik bunyi Pasal 1 Ayat (1) dan (2) UUD 1945 tidak mungkin bisa dipungkiri, bahwa secara yuridis konstitusional Indonesia adalah negara kesatuan yang pemerintahannya berlandaskan pada sistem politik demokrasi. Negara demokrasi Indonesia merupakan sebuah sistem pemerintahan yang meletakan kedaulatan rakyat sebagai sumber kekuasaan tertinggi. Suara rakyat adalah suara Tuhan (vox populi vox dei) merupakan adegium demokrasi yang dipandang paling tepat untuk melukiskannya. Lebih jelas lagi, bahwa demokrasi diartikan sebagai sistem pemerintahan dari rakyat, oleh rakyat dan untuk rakyat (Prabuki dkk, 2018). Dengan berbekal slogan populer di atas hampir semua negara mengaku sistem pemerintahannya adalah demokrasi (Selian dan Melina, 2018).

Meskipun mayoritas negara-negara di dunia sudah mengadopsi dan beradaptasi dengan sistem politik demokrasi, tetapi belum terdapat kesepakatan atau keseragaman, baik dari segi pemaknaan maupun implementasinya dalam kehidupan berbangsa dan bernegara. Tak terkecuali dengan Indonesia yang ditinjau dari perspektif geografis (wilayah) dan demografisnya (penduduk) memiliki sistem politik demokrasi yang sangat unik dan begitu istimewa, bila dibandingkan dengan negara lainnya. Karena dipandang dari segi geografisnya Indonesia adalah negara kepulauan (archipelago state) dengan jumlah pulaunya kurang lebih 17.504 (Lasabuda, 2013). Belum lagi jika ditinjau dari aspek demografisnya, Indonesia adalah negara dengan jumlah penduduk terbanyak ke empat di dunia setelah RRC, India dan 
Amerika Serikat (Indraswari dan Yuhan, 2017). Kombinasi sistem politik demokrasi antara wilayah luas yang dipisahpisahkan lautan dengan tingginya kadar keberagaman di tengah padatnya jumlah penduduk telah menjadi karakteristik yang membedakan Indonesia dengan negara demokrasi lainnya. Dengan kondisi demikian kompleksnya, tidak terbayangkan kesulitan yang dijumpai dan dihadapi bangsa Indonesia dalam membangun kualitas sistem politik demokrasinya.

Rakyat menikmati kebebasan berpendapat serta rakyat menikmati kebebasan berorganisasi. Kebebasan sipil bisa dinikmati meskipun di sisi lain hak sekelompok masyarakat bisa dihilangkan oleh kelompok masyarakat lain. Dalam kondisi seperti ini, beberapa kalangan menilai penerapan demokrasi di Indonesia harus dijiwai dengan ideologi atau dasar negara Republik Indonesia yaitu Pancasila. Pancasila sebagai dasar atau ideologi negara harus diterapkan dalam kehidupan berdemokrasi.

Sebagai negara yang menerapkan demokrasi tentu tidak akan terlepas dari penegakan hak asasi manusia. Dalam negara demokrasi kebebasan masyarakat sangat dihormati, tetapi kebebasan seperti apa? Tentu kebebasan yang bertanggung jawab. Kita tidak bisa menerapkan demokrasi liberal yang menjunjung kebebasan individu secara mutlak yang mengakibatkan sekulerisme dan kapitalisme. Begitupun kita tidak bisa menerapkan demokrasi proletar yang dianut oleh negara-negara sosialis komunis. Negara kita menerapkan demokrasi pancasila dimana demokrasi yang dilandasi nilai-nilai pancasila.

Gerakan sosial baru muncul seiring dengan perubahan bentuk masyarakat. Perkembangan masyarakat kekinian tentu juga menjadi pertimbangan perihal bagaimana mengamati bentuk gerakan sosial yang muncul, strategi yang digunakan, serta visi dan perubahan yang ingin dicapai. Para teroretikus sosial juga telah mengembangkan pemikirannya dalam merumuskan masyarakat kontemporer. Alain Touraine menyebut masyarakat kekinian sebagai masyarakat terprogram (programmed society), Daniel Bell memakai istilah masyarakat Post-Industri, Jean Baudrillard menyebutnya sebagai masyarakat postmodern, Jean-François Lyotard menggunakan istilah masyarakat terkomputerisasi (computerized society), Anthony Gidden punya istilah kapitalisme lanjut. Pada intinya, pemikiran mereka menyebut adanya pengaruh perkembangan teknologi, kapitalisme dan industri yang eksesif terhadap kebudayaan masyarakat.

\section{Rumusan Masalah}

1. Apa pengertian dari definisi demokrasi?

2. Bagaimana demokrasi melalui gerakan sosial?

3. Bagaimana jalannya demokrasi gerakan social?

\section{Tinjauan Pustaka}

Definisi demokrasi yang dikemukakan oleh Joseph Scumpeter yang menyatakan "the democracy method is that institutional arrangement for arriving at political decisions in which individuals acquire the power to decide by means of a competitive struggle for the people votes" (Metode yang demokrasi adalah suatu pengaturan kelembagaan guna mencapai keputusan politik, dimana setiap individu berusaha 
mendapatkan kekuasaan untuk mengambil keputusan lewat kompetisi guna memperoleh suara rakyat). (Schumpeter, 1947).

Gaffar (Sri Wuryan dan Saefullah, 2009:85) mengatakan "democracy relates to the fundamental human rights, which includes freedom of expression, freedom of belief and freedom of action. To avoid chaos, in practice, democracy recognizes such values as responsibility, self discipline, objective, rational, love and care, respect for others, and acceptance of differences of opinions". Berdasarkan pendapat tersebut, demokrasi berkaitan erat dengan hak dasar sebagai manusia, seperti kebebasan berekpresi, kebebasan dalam keyakinan, dan kebebasan berperilaku. Nilai-nilai demokrasi harus dilaksanakan atau dipraktekkan dalam kehidupan sehari-hari seperti tanggung jawab, disiplin diri, berpikir objektif, dan rasional, kasih sayang dan peduli, respek terhadap sesama dan menerima perbedaan pendapat diantara sesama warga masyarakat.

Pengertian Demokrasi Pancasila. Menurut Darmihardjo (Budiyanto, 2005: 54), mengatakan bahwa demokrasi Pancasila adalah paham demokrasi yang bersumber kepada kepribadian dan falsafah hidup bangsa Indonesia, yang perwujudannya adalah seperti dalam ketentuanketentuan Pembukaan UUD 1945. Lebih lanjut Yudi Latif (2011:383) mengatakan dalam demokrasi Pancasila kebebasan individu tidak bersifat mutlak, tetapi harus diselaraskan dengan tanggung jawab sosial

Proses demokratisasi, menurut Heru Nugroho, bisa dilakukan melalui dua fokus. Pertama kompetisi, kedua partisipasi. Proses demokratisasi melalui gerakan sosial baru bergerak di jalan partisipasi, yang mendorong peningkatan jumlah warga yang memperoleh hak-hak politik dan kebebasan. Hak-hak warga yang diperjuangkan kaitannya dengan gerakan sosial baru antara lain perjuangan untuk membuat subyek penguasa berhubungan dengan kehendak para pemilih atau publik dan perjuangan bagi terciptanya emansipasi bagi sekelompok masyarakat marginal yang masih bergantung pada kelompok dominan.

\section{Pembahasan}

Istilah "demokrasi" berasal dari Yunani yang diutarakan di Athena pada abad ke-5 SM. Negara tersebut biasanya dianggap sebagai contoh awal dari sebuah sistem yang berhubungan dengan hukum demokrasi modern. Namun, arti dari istilah ini telah berubah sejalan dengan waktu, dan definisi modern telah berevolusi sejak abad ke-18, bersamaan dengan perkembangan sistem "demokrasi” di banyak negara.

Secara istilah (etimologi) kata demokrasi berasal dari bahasa Yunani demokratia yang berarti "rule of the people", merupakan paduan dari dua kata, demos berarti rakyat dan kratos berarti kekuasaan atau pemerintahan. Dalam ucapan Abraham Lincoln (Presiden Amerika Serikat ke 16) "democracy is government of the people, by the people, and for the people", yaitu pemerintahan dari rakyat, oleh rakyat, dan untuk rakyat. Pada kesempatan yang lain, Abraham Lincoln mengatakan "This country, with its institutions, belongs to the people who inhabit it. Whenever they shall grow weary of the existing government, they can exercise their constitutional rights of amending it, or their revolutionary right to dismember or overthrow it”. (Dikdik B. Arif, 2014: 73). Konsep demokrasi menjadi sebuah kata kunci tersendiri dalam bidang ilmu politik. Hal ini menjadi wajar, sebab demokrasi saat ini disebut-sebut sebagai indikator perkembangan politik suatu Negara. 
Dalam rancangan TAP MPR RI tentang demokrasi pancasila, disebutkan bahwa demokrasi Pancasila adalah norma yang mengatur penyelenggaraan kedaulatan rakyat dan penyelanggaraan pemerintahan negara dalam kehidupan politik, ekonomi, sosial budaya, dan pertahanan keamanan bagi setiap warga negara Republik Indonesia, organisasi kekuatan sosial politik, organisasi kemasyarakatan dan lembaga kemasyarakatan lainnya serta lembagalembaga negara baik di pusat maupun daerah. (Agustam, 2011:83).

Dari beberapa pengertian di atas dapat disimpulkan demokrasi Pancasila adalah demokrasi yang dihayati oleh bangsa dan Negara Indonesia yang dijiwai dan diintegrasikan oleh sila-sila Pancasila atau nilai-nilai luhur Pancasila. Secara luas demokrasi Pancasila berarti kedaulatan rakyat yang berdasarkan pada nilai-nilai Pancasila pada bidang politik, ekonomi, dan sosial. Secara sempit demokrasi Pancasila berarti kedaulatan rakyat yang dilaksanakan menurut hikmat kebijaksanaan dalam permusyawaratan perwakilan.

Demokratisasi di Indonesia Melalui gerakan Sosial Baru yaitu gerakan reformasi 1998 bisa dikatakan membuka pintu demokratisasi dan desentralisasi sistem di Indonesia.Meskipun sistem demokrasi langsung baru diterapkan tahun 2004. Juga, meskipun sistem demokrasi diinstal pada feodalisme, kapitalisme, agama dan tradisi. Kita bisa melihat bagaimana dalam sistem demokrasi di Indonesia masih ada sistem feodal/tradisi seperti di Yogyakarta dan Solo, serta ada juga sistem syariah seperti di Aceh. Tetapi setidaknya, gerakan sosial baru perlahan muncul sebagai efek demokratisasi dan dorongan kepada bentuk demokrasi yang kerap disebut sebagai demokrasi langsung.Dalam demokrasi langsung, gerakan sosial baru merupakan agen perubahan. Secara umum gerakan sosial muncul sebagai bentuk ketidakpuasan dengan kebijakan yang ada. Bentuk keberhasilan gerakan sosial ditentukan dari sejauh mana perubahan kebijakan mampu mengakomodasi tuntutan atau partisipasipublik dalam perumusan kebijakan.Gerakan sosial menegaskan demokrasi langsung yang dianggap lebih dekat dengan kepentingan publik daripada demokrasi liberal, yang berbasis delegasi untuk representasi rakyat yang hanya bisa dikontrol saat pemilihan, dan demokrasi terorganisir yang berbasis mediasi oleh partai politik. Demokrasi langsung bersifat partisipatoris, otoritasnya didelegasikan untuk isu-isu tertentu yang berkaitan dengan kepentingan publik, dengan syarat tuntutan kesetaraan dan perlindungan hak demokratis untuk minoritas. Ia bersifat desentral dan menekankan kebijakan atau keputusan mesti diambil sedekat mungkin dengan kehidupan rakyat.

Gerakan sosial merupakan bentuk pembukaan ruang-ruang dalam penyaluran aspirasi publik sebagai bentuk proses demokratisasi. Sedangkan gerakan sosial memiliki ciri:

(1) Terlibat dalam relasi konfliktual dengan lawan yang spesifik.

(2) Hubungan dibentuk oleh jaringan informal yang solid.

(3) Berbagi identitas bersama. Perbedaanya lagi, gerakan sosial baru memiliki karakter utama yakni protes publik yang damai/non-kekerasan, yang membedakannya dengan gerakan politik melalui jalur partisipasi publik konvensional seperti voting atau lobi dalam perwakilan politik.

Perbedaanya lagi, gerakan sosial baru memiliki karakter utama yakni protes publik yang damai/non-kekerasan, yang membedakannya dengan gerakan politik melalui jalur partisipasi publik konvensional seperti voting atau lobi dalam perwakilan politik. 
Strategi gerakan sosial baru turut memunculkan nilai dan bahasa simbolik tertentu. Kalau di Barat, nilai-nilai yang digunakan dalam gerakan sosial adalah wacana untuk membongkar opresi modern seperti kapitalisme, tradisi keluarga, seksualitas, agama atau media massa. Sehingga wacana yang muncul adalah feminisme, liberalisme, neo-marxist. Sedangkan gerakan sosial baru di Indonesia yang belum tuntas membongkar opresi kultural, justru menggunakan nilai opresi kultural seperti nilai-nilai tradisi sebagai titik tolak perjuangannya, serta sebagai kohesi solidaritasnya. Nilai kultural yang opresif bagi Barat, sebaliknya digunakan oleh gerakan sosial Indonesia untuk membongkar opresi ketidakadilan. Gerakan selamatkan Rembang memunculkan nilai/filosofi kejawen perihal hubungan antara manusia dengan alam. Gerakan Bali tolak Reklamasi memunculkan nilai-nilai adat seperti puputan (perang habis-habisan sampai mati).

\section{Kesimpulan}

Demokrasi adalah sebuah kata yang begitu sering diucapkan. Namun, makin banyak ia dibahas makin terasa betapa sulit mencari contoh tentang negara yang memenuhi tatanan kepolitikan demokrasi secara sempurna. Di Indonesia, pencarian terhadap sosok demokrasi pun terus digelar, baik pada aras implementasi sistem politik maupun kajian akademik. Dalam aras akademik, sejumlah makalah dikupas habi-habisan dalam berbagai seminar. Sejumlah buku, artikel pidato para pakar dan politisi, telah diterbitkan dalam jurnal ilmiah, koran dan majalah umum.

Reformasi 1998 merupakan pintu masuk menuju babak baru tradisi demokrasi Indonesia. Agenda selanjutnya lebih panjang dan tak mudah, yakni proses mengubah tatanan yang tradisional menjadi demokratis. Proses demokratisasi Indonesia menempuh jalan terjal karena masih belum menuntaskan opresi-opresi tradisional. Demokratisasi di Indonesia cenderung mengarah ke demokratisasi kapitalisme, demokrasi feodalisme dan demokratsasi agama. Nilai-nilai tradisi tidak dipertanyakan, hanya mengalami demokratisasi dengan masih memegang teguh nilai-nilai tradisi. Setidaknya hal ini tercermin dari bentuk gerakan sosial baru di Indonesia.

\section{Daftar Pustaka}

Prasisko, Y. G. (2016). Gerakan Sosial Baru Indonesia: Reformasi 1998 dan Proses Demokratisasi Indonesia. Jurnal Pemikiran Sosiologi, 3(2), 9-16.

Purnaweni, H. (2004). Demokrasi Indonesia: Dari masa ke masa. Jurnal Administrasi Publik Vol 3 No. 2, UNPAR, 2004., 3. Gandanama, Apiek. Memaknai Demokrasi Pancasila.

Santika, I. G. N., Purnawijaya, I. P. E., \& Sujana, I. G. (2019). Membangun Kualitas Sistem Politik Demokrasi Indonesia Melalui Pemilu Dalam Perspektif Integrasi Bangsa Dengan Berorientasikan Roh Ideologi Pancasila. In Seminar Nasional Hukum Dan Kewarganegaraan (Vol. 1, No. 1, pp. 74-85).

Siyoto, S., \& Sodik, M. A. (2015). Dasar metodologi penelitian. Literasi Media Publishing. 